\title{
IN VITRO CYTOTOXIC AND APOPTOTIC EFFECT OF PASSIFLORA FOETIDA AGAINST CERVICAL CANCER CELLS AND ITS FOURIER TRANSFORM INFRARED PROFILING
}

\author{
DHEEBAN SHANKAR P ${ }^{1,2 *}$, BASKER $S^{3}$, KARTHIK $S^{2}$ \\ ${ }^{1}$ Research and Development Centre, Bharathiar University, Coimbatore, Tamil Nadu, India. ${ }^{2}$ Department of Biotechnology, Nandha Arts \\ and Science College, Erode, Tamil Nadu, India. ${ }^{3}$ Department of Botany, Government Arts College (Autonomous), Salem, Tamil Nadu, India. \\ Email: deepanbala@gmail.com \\ Received: 25 May 2017, Revised and Accepted: 10 July 2017
}

ABSTRACT

Objective: This study was aimed on the analysis of cytotoxic and apoptotic action of Passiflora foetida followed by identification of the functional groups responsible for the activity.

Methods: In this study, cytotoxic and apoptotic effect of methanol extract of $P$. foetida were analyzed by treating HeLa cell line cultures with different concentrations of the extract $(25,50,75,100$, and $125 \mu \mathrm{g} / \mathrm{ml})$, and thereby the activity was ratified by $3-(4,5$-dimethylthiazol-2-yl)-2,5diphenyltetrazolium bromide (MTT) assay and propidium iodide staining. The functional groups of the bioactive compounds for the effectiveness of the treatment were known by Fourier transform infrared spectroscopy analysis (FTIR).

Results: The cytotoxic activity was found to be increased in a dose-dependent manner with inhibitory concentration value of $21.55 \mu \mathrm{g} / \mathrm{ml}$ and showed an effective apoptosis. Further, FTIR analysis confirmed the presence of functional groups of alkaloids, flavonoids, saponins, steroids, terpenoids, phenols and cardiac glycosides which might be responsible for the aforesaid activity.

Conclusion: The cytotoxic and apoptotic action of $P$. foetida was proved to be very effective, and the tenable functional groups were identified.

Keywords: Passiflora foetida, Cytotoxic, Apoptotic, 3-(4,5-dimethylthiazol-2-yl)-2,5-diphenyltetrazolium bromide, Propidium iodide.

(C) 2017 The Authors. Published by Innovare Academic Sciences Pvt Ltd. This is an open access article under the CC BY license (http://creativecommons. org/licenses/by/4. 0/) DOI: http://dx.doi.org/10.22159/ajpcr.2017.v10i11.20226

\section{INTRODUCTION}

India is bestowed with a rich wealth of medicinal plants which have been a valuable source of natural products for maintaining human health. Traditional medicine has been practiced for many centuries' especially in rural areas due to its common availability and low cost. The use of medicinal plants for curing diseases had been recorded in the history of all civilizations [1]. The Medicinal plants are considered to be biosynthetic laboratory for its phytochemicals which augment physiological and therapeutic effects [2]. The cancer diseases are fatal to human lives and it is the second leading cause of death in the world. Still no effective medicines are made to treat most cancers [3]. Cervical cancer is found to be the second most common cancer among the women worldwide. Earlier investigation had suggested that infection with human papilloma virus may play a major role in cervical cancer. At present, the treatments available for cervical cancer are mainly synthetic drugs which may induce serious side effects that limit the use of such drugs [4], and also the cancer treatment has become very expensive [5]. Moreover, the anticancer compounds that are available in the market have been isolated from plants in large numbers [6]. Therefore, the use of plants and its products may be the exclusive choice for the prevention and treatment of cancer with lesser side effects and will be an alternative method. At present, the researchers are also focusing greatly on folk medicine to develop better and effective drugs for cancer. Although the properties and doses of medicinal plants are known to the traditional users by practices, still unaware of scientific reasons behind its uses $[7,8]$. Hence, it will be highly appreciated if more researches are carried out to know the scientific reasons and the actual mechanism of curing diseases either by in vitro or in vivo experiments. In such a way, this study was aimed by subjecting the commonly used cervical cancer cell line (HeLa cells) to analyze the anticancer effect of widely distributed common medicinal plant, Passiflora foetida and to know the functional groups of the bioactive constituent responsible for it through Fourier Transform Infrared (FTIR) profiling. P. foetida is an exotic and fast growing perennial vine belongs to the family Passifloraceae reported to have pharmacological properties, viz., antimicrobial [9], antiinflammatory [10], antioxidant [11], antidepressant [12], antidiarrheal and analgesic [13], antinociceptive [14] and antiulcer activities [15]; also used to treat erysipelas and skin diseases with inflammation [16], asthma and biliousness [17], anxiety, insomnia, convulsion, sexual dysfunction, cough and cancer [18]. The other species of the Passifloraceae family such as Passiflora tetrandra and Passiflora edulis were found to exhibit cytotoxic effect against P-388 murine leukemia cells [19] and CCRF-CEM leukemia cells [20], respectively. Although the report on the anticancer activity of $P$. foetida was available for leaves against breast cancer (MCF 7) cell line [21], fruits against leukemic cell lines (K562, U937, Molt 4, and HL60) [22], the present investigation on cytotoxic and apoptotic potential of methanol extract of $P$. foetida leaves against cervical cancer (HeLa cells) cell line is the first report to the best of our knowledge.

\section{METHODS}

Collection of plant sample and preparation of extract

The leaves of $P$. foetida were collected from in and around Erode District, Tamil Nadu, India and taxonomically authenticated by BSI, TNAU, Coimbatore, with reference number BSI/SRC/5/23/2014-15/ Tech-1085. The leaves were detached from the healthy collected twigs and then washed thoroughly with tap water followed by distilled water, dried under shadow for about 15 days and then powdered well to extract with methanol according to the earlier described methods of Woisky and Salatino, Cunha et al., Phrompittayarat et al., and Sasidharan et al. [23-26]. The reddish brown precipitate obtained as crude extract was used for the cytotoxic studies and FTIR analysis. 


\section{Cell culture}

The cytotoxic effect of $P$. foetida was analyzed using HeLa cell line obtained from National Center for Cell Science, Pune, Maharashtra, India, aseptically maintained in Dulbecco's Modified Eagle Medium (DMEM) supplemented with 10\% fetal bovine serum, L-glutamine $(1 \%)$, streptomycin and penicillin $(1 \%)$ in a humidified incubator with $5 \%$ carbondioxide at $37^{\circ} \mathrm{C}$.

Analysis of cytotoxicity by 3-(4,5-dimethylthiazol-2-yl)-2,5diphenyltetrazolium bromide (MTT) assay

The methanol extract of $P$. foetida was tested for its cytotoxic effect on HeLa cells and was determined by MTT assay [27]. Cells were seeded at a density of $1 \times 10^{5}$ cells/well in a 96 well plate. The cells were allowed to adhere for $24 \mathrm{hrs}$ and then treated with plant extract at different concentrations $(25-125 \mu \mathrm{g} / \mathrm{ml})$ for $24 \mathrm{hrs}$. The culture medium was removed and $20 \mu \mathrm{l}$ of MTT ( $5 \mathrm{mg} / \mathrm{ml}$ in DMEM) was added to each well followed by incubation for $2 \mathrm{hrs}$ to visualize the formazan crystals under a light microscope. The absorbance was measured at a wavelength of $570 \mathrm{~nm}$ using a microplate enzyme-linked immunosorbent assay reader after dissolving the formazan crystals in $100 \mu$ lisopropanol [28]. The effect of plant extract on HeLa cell proliferation was assessed as percentage cell viability over that of control, where vehicle treated control cells ( $0.1 \%$ dimethyl sulfoxide) were taken as $100 \%$ viable. The percentage inhibition of the cytotoxic activity was calculated as follows:

$\%$ Inhibition $\left[\left(\right.\right.$ Absorbance $_{\text {control }}-$ Absorbance $\left._{\text {test }}\right) /$ Absorbance $\left._{\text {control }}\right] \times 100$

\section{Determination of apoptosis by propidium iodide (PI) staining}

The apoptotic action of $P$. foetida on HeLa cells were assessed using fluorescent dye, PI according to the method described [29,30]. HeLa cells $1 \times 10^{4}$ cells/well were seeded in a 24 well plate and grown until confluent. The cells were treated with plant extract at different concentrations $(25-125 \mu \mathrm{g} / \mathrm{ml})$ for $24 \mathrm{hrs}$. The cells were washed with ice cold phosphate buffered saline (PBS) and fixed with $70 \%$ ethanol for 30 minutes. After fixation, the plates were once again rinsed with ice-cold PBS followed by staining with $200 \mu \mathrm{l}$ of PI $(500 \mu \mathrm{M})$ for $1 \mathrm{hr}$; further, the plates were washed twice with ice-cold PBS and the nuclear staining of the cells which undergone apoptosis was observed under a fluorescence microscope.

\section{Statistical analysis}

The data obtained for cytotoxicity assay was analyzed using SPSS (16.00) to calculate inhibitory concentration $\left(\mathrm{IC}_{50}\right)$ value.

\section{FTIR spectrum profiling}

The methanol extract of $P$. foetida was mixed with $\mathrm{KBr}$ salt using a mortar and pestle thereby compressed into a thin pellet and subjected to record the functional groups responsible for the activity through infrared spectrum on a Shimadzu FTIR spectrometer 8000 series over the frequency ranges between 4000 and $400 \mathrm{~cm}^{-1}$.

\section{RESULTS AND DISCUSSION}

\section{Cytotoxic and apoptotic action}

The meticulous analysis of cytotoxic and apoptotic action of $P$. foetida (Fig. 1) over HeLa cell line had shown dose-dependent effect in a highly significant manner. The cytotoxic effect was confirmed by percentage of cell inhibition with respect to MTT assay, and the concentration of the methanol extract required to inhibit $50 \%$ viability of the cells was determined as $\mathrm{IC}_{50}$ value and calculated to be $21.55 \mu \mathrm{g} / \mathrm{ml}$ (Table 1) which revealed the significant toxicity compared to the other medicinal and nonmedicinal plants reported against cervical cancer cells [31,32]. The viable cells with active metabolism converted MTT into a purple colored formazan product which served as a visual marker of the viable cells, and the absorbance measured at $570 \mathrm{~nm}$ was used to find the $\mathrm{IC}_{50}$ of extract over the HeLa cells. The $\mathrm{IC}_{50}$ value obtained in this study had proved that $P$. foetida possess an effective cytotoxic effect. As the crude extract possessing an $\mathrm{IC}_{50}<20 \mu \mathrm{g} / \mathrm{ml}$ are considered to have active compounds against the cancer cells according to the criteria of Standard National Cancer Institute $[33,34]$, the $\mathrm{IC}_{50}$ value of this study was found to

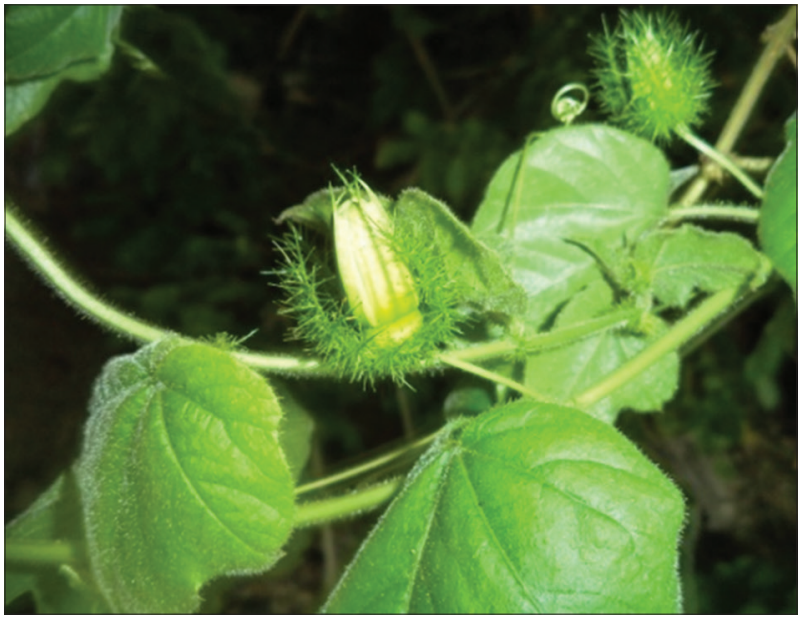

Fig. 1: Habit of Passiflora foetida

Table 1: Cytotoxic effect of Passiflora foetida

\begin{tabular}{lll}
\hline $\begin{array}{l}\text { Concentration of the } \\
\text { extract }(\boldsymbol{\mu g} / \mathbf{m l})\end{array}$ & \% of inhibition & IC $_{\mathbf{5 0}}$ value $(\boldsymbol{\mu g} / \mathbf{m l})$ \\
\hline Control & 0 & 21.55 \\
25 & 58 & \\
50 & 62.62 & \\
75 & 63.66 & \\
100 & 66.08 & \\
125 & 74.74 & \\
\hline
\end{tabular}

$\mathrm{IC}_{50}$ : Inhibitory concentration

be nearer to the above criteria which strongly recommend and serve as an experimental evidence to utilize $P$. foetida as a natural source of drugs against cancer cells. The uptake of PI was found to increase with increase in the concentration of the extract corresponding to the number of nonviable cells which indicated the apoptotic induction and was clearly visible under fluorescence microscope (Fig. 2). The morphological changes and the characteristics of apoptotic bodies such as blebbing, cell breakage and chromatin condensation were also visualized by PI staining and observed to be similar to the results of the study by Durgha et al. [4]. The phytocompounds such as flavonoids, phenolic acids and tannins were found to be the potential sources of anticarcinogenic, anticancer, antimicrobial and antioxidant activities $[35,36]$. Almost all parts of the plant, $P$. foetida were reported to contain alkaloids, flavonoids, tannins, phenols, steroids, cardioglycosides, saponins and terpenoids [37]. As saponins were found to have membrane permeabilizing property and interfere with the replication of cell DNA, it might have played a role in preventing the growth and division of cancer cells. Furthermore, it was suggested that the phytochemicals in the plants working together with nutrients may slow the aging process and reduce the risk of various diseases including cancer $[38,39]$. Most of the phytochemicals possess antioxidant potential especially flavonoids which protect the cells against oxidative damage thereby reduces the risk of developing certain types of cancer [40]. The results of this study was analyzed to suspect that the matrix-metalloprotease MMP-2 and MMP-9, enzymes involved in the tumour invasion, metastasis and angiogenesis might also be inhibited by methanol extract prepared from leaves of $P$. foetida as earlier report on such enzyme inhibition was available for aqueous extract of fruits of P. edulis and P. foetida [41]. Hence, this study had shown the efficacy of P. foetida for the cytotoxicity and apoptotic induction toward HeLa cells, thus suggesting the protection against the cervical cancer cells.

\section{FTIR spectrum profiling}

The FTIR spectrum recorded for the methanol extract of $P$. foetida had shown various number of peaks as mentioned (Fig. 3). The peak corresponds to functional group of particular phytoconstituent was identified, interpreted and represented (Table 2) according 

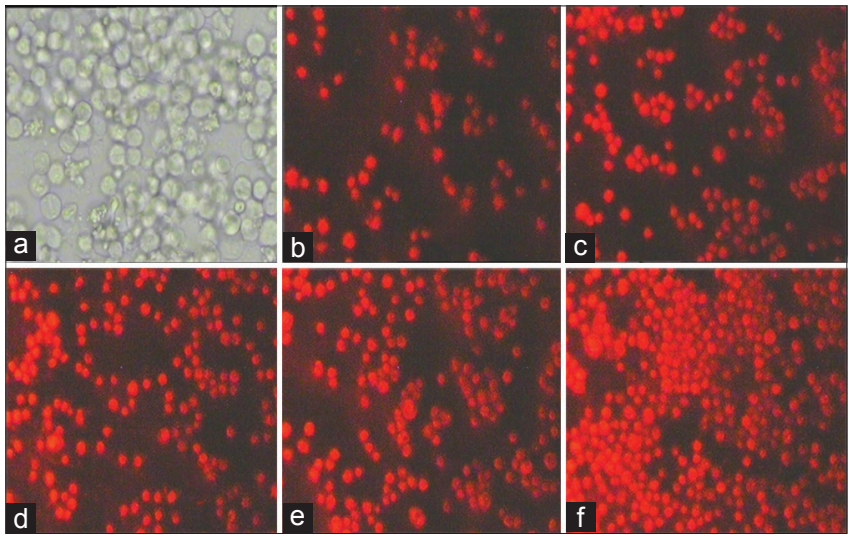

Fig. 2: Apoptotic effect of Passiflora foetida on HeLa cells.

(a) Controls, (b-f), represent the apoptotic induction of methanol extract at a concentration of $25,50,75,100$, and $125 \mu \mathrm{g} / \mathrm{ml}$, respectively

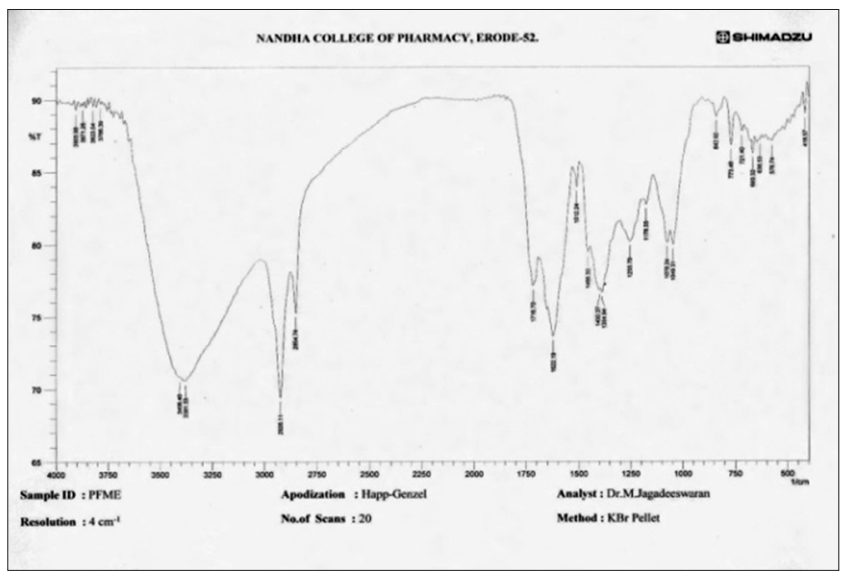

Fig. 3: Fourier transform infrared spectrum of Passiflora foetida methanol extract

to the standard reported references [42-48]. The C-0 stretching at $1078.24 \mathrm{~cm}^{-1}$ revealed the ethers. $\mathrm{CH}_{2}$ and $\mathrm{CH}_{3}$ bending peak at $1456.30 \mathrm{~cm}^{-1}$ and $721.40 \mathrm{~cm}^{-1}$ revealed the aromatic compounds and was identified and found to be similar to the FTIR report of Aerva lanata root extract [49] which may strongly support to use the leaves of widely distributed and commonly available P. foetida instead of root of $A$. lanata where it is the seasonal and not abundant. The spectral peak at $1716.70 \mathrm{~cm}^{-1}$ indicate $\mathrm{C}=0$ stretching which may corresponds to acylic or six memberd ketone groups and was found to be the characteristics of saponins as it is the strong and supporting evidence to the earlier report saying that $P$. foetida is rich in saponins [50]. The C-O stretch at $1255.70 \mathrm{~cm}^{-1}$ revealed the presence of cardiac glycosides and the strong FTIR spectroscopic finger print peaks at $2854.74 \mathrm{~cm}^{-1}$ and $2926.11 \mathrm{~cm}^{-1}$ due to $\mathrm{C}-\mathrm{H}$ stretching corroborated the presence of alkane groups and analyzed to be the characteristics of terpene compounds according to the report of Paulraj et al., [37]. The broad peak at $3406.40 \mathrm{~cm}^{-1}$ showed an $\mathrm{O}-\mathrm{H}$ stretching and indicated the presence of phenol or carbohydrate or alcohol or quinone or carboxylic acid. The presence of quinone may ratify the richness of flavonoids reported to be the major phytoconstituents of $P$. foetida with respect to the previous report and thus it clearly supports the current study [51]. The peak at $3381.33 \mathrm{~cm}^{-1}$ indicated the $\mathrm{N}-\mathrm{H}$ stretch corresponding to primary and secondary amines and found to be the confirmation of alkaloid components. The peak at $1178.5 \mathrm{~cm}^{-1}$ and $1384.9 \mathrm{~cm}^{-1}$ confirmed the presence of thio group and nitro compounds, respectively. The presence of ketone and alkene groups were revealed by the peak at $1622.19 \mathrm{~cm}^{-1}$. The peak at $1255.70 \mathrm{~cm}^{-1}, 669.32 \mathrm{~cm}^{-1}, 576.74 \mathrm{~cm}^{-1}$, $639.53 \mathrm{~cm}^{-1}, 418.57 \mathrm{~cm}^{-1}, 773.48 \mathrm{~cm}^{-1}$ and $842.92 \mathrm{~cm}^{-1}$ were the
Table 2: FTIR peak value and its functional groups

\begin{tabular}{|c|c|c|}
\hline Frequency $\left(\mathrm{cm}^{-1}\right)$ & Component (peaks) & Functional groups \\
\hline 721.4 & $-\mathrm{CH} 2$ (bend) & Aromatics \\
\hline 1456.3 & -CH3 (bend) & \\
\hline 1078.24 & C-O stretch & Ethers \\
\hline 1716.7 & $\mathrm{C}=0$ stretch & $\begin{array}{l}\text { Acyclic or six } \\
\text { membered ketone } \\
\text { group }\end{array}$ \\
\hline $\begin{array}{l}2854.74 \\
2926.11\end{array}$ & C-H stretch & Alkanes \\
\hline 3406.4 & $\mathrm{O}-\mathrm{H}$ stretch & $\begin{array}{l}\text { May be carbohydrate } \\
\text { or alcohol or phenol } \\
\text { or Quinone or } \\
\text { carboxylic acids }\end{array}$ \\
\hline 3381.33 & $\mathrm{~N}-\mathrm{H}$ stretch & $\begin{array}{l}\text { Primary and } \\
\text { secondary amines }\end{array}$ \\
\hline 1178.55 & $-\mathrm{C}=\mathrm{S}$ & Thio group \\
\hline 1384.9 & $\mathrm{~N}=\mathrm{O}$ & Nitro compounds \\
\hline 1622.19 & $\begin{array}{l}\mathrm{C}=\mathrm{O} \\
\mathrm{C}=\mathrm{C}\end{array}$ & $\begin{array}{l}\text { Ketones } \\
\text { Alkenes }\end{array}$ \\
\hline 1255.7 & C-F/C-O stretch & $\begin{array}{l}\text { Halides or Esters or } \\
\text { polyol }\end{array}$ \\
\hline $\begin{array}{l}669.32 \\
576.74 \\
639.53\end{array}$ & $\mathrm{C}-\mathrm{Br}$ & Halides \\
\hline 418.57 & C-I & \\
\hline $\begin{array}{l}773.48 \\
842.92\end{array}$ & $\mathrm{C}-\mathrm{Cl}$ & \\
\hline
\end{tabular}

FTIR: Fourier transform infrared

characteristics of halide groups. Moreover, the $\mathrm{C}-\mathrm{O}$ stretching peak at $1255.70 \mathrm{~cm}^{-1}$ affirmed the presence of esters which were due to the availability of steroids and terpenoids. The presence of phytochemicals analyzed in the methanol extract of $P$. foetida was found to be similar to the methanol leaf extract of Datura metel which also had shown the higher anticancer property against MCF-7 cell line [52]. The FTIR spectral profiling of methanolic extract of Myristica dactyloides fruit revealed the presence of potential bioactive compounds such as alkaloids, glycosides, flavonoids, and tannins which strongly supports the present work [53]. Thus, the findings of our study had confirmed the presence of functional groups of alkaloids, flavonoids, saponins, steroids, terpenoids, phenols, and cardiac glycosides which might have caused the cytotoxicity and apoptosis.

\section{CONCLUSION}

The phytochemicals in plants are having the power and efficacy to cure various diseases and disorders. In such away, this study revealed that the natural source of drugs had acted as a best remedy for the cervical cancer which could be a basement for further analysis against other cancer cells. FTIR analysis ratified the presence of functional groups of the phytocompounds such as alkaloids, flavonoids, saponins, steroids, terpenoids, phenols, and cardiac glycosides with respect to its corresponding peaks. The cytotoxic and apoptotic activity might be enhanced either by individual component or by mixture of compounds that were identified from our investigation in the methanol extract of $P$. foetida. Hence, the actual constituents responsible for curing property can be purified in the near future for the commercialization and betterment of the society to assuage the risk of cancer.

\section{ACKNOWLEDGMENT}

The authors are thankful to the Management, the Principal and the Department of Biotechnology, Nandha Arts and Science College, Erode and the Department of Pharmaceutics, Nandha College of Pharmacy, Erode, TN and Dr. R. Thirugnanasampandan, Assistant Professor, Department of Biotechnology, Kongunadu Arts and Science College, Coimbatore, Tamil Nadu, India for providing necessary facilities to carry out this work successfully. 


\section{REFERENCES}

1. Dfeudis FV. Pharmacological Activities and Clinical Applications of Ginkgo biloba Extract. Paris: Elsevier, Elsevier Editions Scientifiques; 1991. p. 187.

2. Barthel A, Reuter G. Biochemistry and physiology of isoprenoid guanidines, especially (4-hydroxy-3-methyl-2-buten-1-yl) guanidine in Galega officinalis. Pharmazie 1968;23:26-33.

3. Cai Y, Luo Q, Sun M, Corke H. Antioxidant activity and phenolic compounds of 112 traditional Chinese medicinal plants associated with anticancer. Life Sci 2004;74(17):2157-84.

4. Durgha H, Thirugnanasampandan R, Ramya G, Ramanth MG. Inhibition of inducible nitric oxide synthase gene expression (iNOS) and cytotoxic activity of Salvia sclarea L. essential oil. J King Saud Uni Sci 2016;28(4):390-5.

5. Monks NR, Bordignon SA, Ferraz A, Machado KR, Faria DH, Lopes RM, et al. Anti-tumor screening of Brazilian plants. Pharm Biol 2002;40(8):603-16.

6. Newman DJ, Cragg GM. Natural products as sources of new drugs over the 30 years from 1981 to 2010. J Nat Prod 2012;75(3):311-35.

7. Gurib-Fakim A. Medicinal plants: Traditions of yesterday and drugs of tomorrow. Mol Aspects Med 2006;27(1):1-93.

8. Kokate CK, Purohit AP, Gokhale SB. Pharmacognosy. $30^{\text {th }}$ ed. Pune, India. Nirali Prakashan; 2004. p. 593-7.

9. Mohanasundari C, Natarajan D, Srinivasan K, Umamaheswari S, Ramachandran A. Antibacterial properties of Passiflora foetida L.-a common exotic medicinal plant. Afr J Biotechnol 2007;6(23):2650-3.

10. Fernandes J, Noronha MA, Fernandes R. Evaluation of antiinflammatory activity of stems of Passiflora foetida Linn. In rats. Res J Pharm Biol Chem Sci 2013;4(2):1236-41.

11. Sasikala V, Saravanan S, Parimelazhagan T. Evaluation of antioxidant potential of different parts of wild plant Passiflora foetida L. J Appl Pharm Sci 2011;1(4):89-96.

12. Santosh P, Venugopl R, Nilakash AS, Kunjbihari S, Mangala L. Antidepressant activity of methanolic extract of Passiflora foetida leaves in mice. Int J Pharm Pharm Sci 2011;3(1):112-5.

13. Asadujjaman M, Mishuk AU, Hossain MA, Karmakar UK. Medicinal potential of Passiflora foetida L. plant extracts: Biological and pharmacological activities. J Integr Med 2014;12(2):121-6.

14. Rahman A, Hossain A, Hasan S, Hossain MG. Antinociceptive, antidiarrhoeal and cytotoxic activities of Passiflora foetida Linn. Pharmacol Online 2011;1:228-36.

15. Sathish R, Sahu A, Natarajan K. Antiulcer and antioxidant activity of ethanolic extract of Passiflora foetida L. Indian J Pharmacol 2011;43(1):336-9.

16. Chopra RN, Badhwar RL, Ghosh S. Poisonous Plants of India. Calcutta, India: 1949. p. 469-72.

17. Ambasta SP. The Useful Plants of India. New Delhi, India: Publication and Information Directorate, CSIR; 1986. p. 433-7.

18. Patil AS, Paikrao HM, Patil SR. Passiflora foetida Linn: A complete morphological and phytopharmacology review. Int J Pharm Bio Sci 2013;4(1):285-96.

19. Perry NB, Albertson GD, Blunt JW, Cole AL, Munro MH, Walker JR. 4-Hydroxy-2-cyclopentenone: An anti-Pseudomonas and cytotoxic component from Passiflora tetrandra. Planta Med 1991;57(2):129-31.

20. Kuete V, Dzotam JK, Voukeng IK, Fankam AG, Efferth T. Cytotoxicity of methanol extracts of Annona muricata, Passiflora edulis and nine other Cameroonian medicinal plants towards multifactorial drug resistant cancer cell lines. Springer Plus 2016;5(1):1-12.

21. Vijayalaxmi S, Bhosale UP. Screening of Passiflora foetida extracts as anticancer agents on MCF 7 cell line. Bioinfolet 2013;10(3a):808-10.

22. Ampasavate C, Okonogi S, Anuchapreeda S. Cytotoxicity of extracts from fruit plants against leukemic cell lines. Afr J Pharm Pharmacol 2010;4(1):13-21.

23. Woisky RG, Salatino A. Analysis of propolis: Some parameters and procedures for chemical quality control. J Apic Res 1998;37(2):99-105.

24. Cunha LB, Sawaya AC, Caetano FM, Shimizu MT, Marcucci MC, Drezza FT, et al. Factors that influence the yield and composition of Brazilian propolis extracts. J Braz Chem Soc 2004;15(6):964-70.

25. Phrompittayarat W, Putalun W, Tanaka H, Jetiyanon K, Wittaya-Areekul S, Ingkaninan K. Comparison of various extraction methods of Bacopa monnier. Naresuan Univ J 2007;15(1):29-34.

26. Sasidharan S, Darah I, Jain K. In vivo and in vitro toxicity study of Gracilaria changii. Pharm Biol 2008;46(6):413-7.

27. Yu JQ, Lei JC, Zhang XQ, Yu HD, Tian DZ, Liao ZX, et al. Anticancer, antioxidant and antimicrobial activities of the essential oil of Lycopus lucidus Turcz. var. Hirtus regel. Food Chem 2011;126(4):1593-8.
28. Lau CB, Ho CY, Kim CF, Leung KN, Fung KP, Tse TF, et al. Cytotoxic activities of Coriolus versicolor (Yunzhi) extract on human leukemia and lymphoma cells by induction of apoptosis. Life Sci 2004;75(7):797-808

29. Brana C, Benham C, Sundstrom L. A method for characterising cell death in vitro by combining propidium iodide staining with immunohistochemistry. Brain Res Brain Res Protoc 2002;10(2):109-14.

30. Baskic D, Popovic S, Ristic P, Arsenijevic NN. Analysis of cycloheximide-induced apoptosis in human leukocytes: Fluorescence microscopy using annexin V/propidium iodide versus acridin orange/ ethidium bromide. Cell Biol Int 2006;30(11):924-32.

31. Booth GM, Malmstrom RD, Kipp E, Paul A. Cytotoxicity of selected medicinal and non medicinal plant extracts to microbial and cervical cancer cells. J Biomed Biotechnol 2012;2012:1-4

32. Ganesh G, Abhishek T, Saurabh M, Sarada NC. Cytotoxic and apoptosis induction potential of Mimusops elengi L. in human cervical cancer (SiHa) cell line. J King Saud Univ Sci 2014;26:333-7.

33. Chen CF, Hwang JM, Lee W, Chiang HC, Lin JC, Chen HY. Search for anti-tumor agents from Chinese herbs. I. Anti-tumor screening method. Zhonghua Yi Xue Za Zhi (Taipei) 1988;41(3):177-84.

34. Geran RI, Greenberg NH, Mac Donald MM. Protocols for screening chemical agents and natural products against animal tumors and other biological systems. Cancer Chemother Rep 1972;3(2):1-103.

35. Tavassoli S, Djomeh ZE. Total phenols, antioxidant potential and antimicrobial activity of methanol extract of Rosemary (Rosmarinus officinalis L). Glob Vet 2011;7(4):337-41.

36. Bruneton J. Pharmacognosy, Phytochemistry and Medicinal Plants. Paris, France: Lavoisiler Publishing; 1995.

37. Paulraj JA, Subharamanian H, Suriyamoorthy P, Kanakasabapathi D. Phytochemical screening, GC-MSanalysis andenzymeinhibitoryactivity of Passiflora foetida L. Indo Am J Pharm Res 2014;4(8):3526-34.

38. Tiwari P, Kumar B, Kaur M, Kaur G, Kaur H. Phytochemical screening and extraction: A review. Int Pharm Sci 2011;1(1):98-106.

39. Temidayo AR. Extraction and isolation of flavonoids present in the methanolic extract of leaves of Acanthospermum hispidum Dc. Glob J Med Plant Res 2013;1(1):111-23.

40. Harborne H. Comparative Biochemistry of the Flavonoids. London, New York: Academic Press Inc.; 1967

41. Puricelli L, Dell'Aica I, Sartor L, Garbisa S, Caniato R. Preliminary evaluation of inhibition of matrix-metalloprotease MMP-2 and MMP-9 by Passiflora edulis and $P$ foetida aqueous extracts. Fitoterapia 2003;74(3):302-4.

42. Maobe MA, Nyarango RM. Fourier transformer infra-red spectrophotometer analysis of Warburgia ugandensis medicinal herb used for the treatment of diabetes, malaria and pneumonia in Kisii region, southwest Kenya. Glob J Pharmacol 2013;7(1):61-8.

43. Bobby N, Wesely EG, Johnson M. FT-IR studies on the leaves of Albizia lebbeck Benth. Int J Pharm Pharm Sci 2012;4 Suppl 3:293-6.

44. Muruganantham S, Anbalagan G, Ramamurthy N. FT-IR and SEMEDS comparative analysis of medicinal plants, Eclipta alba Hassk and Eclipta prostrata Linn. Rom J Biophys 2009;19(4):285-94.

45. Donald LP, Gary ML, Gorge SK, Randall GE. Introduction to Organic Laboratory Techniques. $2^{\text {nd }}$ ed. Pacific Grove, CA: Brooks/Cole; 2005. p. 1028.

46. Paul RK, Irudayaraj V, Johnson M, Patric RD. Phytochemical and antibacterial activity of epidermal glands extract of Christella parasitica (L.) H. Lev. Asian Pac J Trop Biomed 2011;1(1):8-11

47. Rajan $\mathrm{S}$, Thirunalasundari $\mathrm{T}$, Jeeva $\mathrm{S}$. Anti-enteric bacterial activity and phytochemical analysis of the seed kernel extract of Mangifera indica Linnaeus against Shigella dysenteriae (Shiga, Corrig.) Castellani and Chalmers. Asian Pac J Trop Med 2011;4(4):294-300.

48. Skoog DA, Holler FJ, Crouch SR. Principles of Instrumental Analysis. $6^{\text {th }}$ ed. Chichester, UK: Wiley; 2007. p. 1039.

49. Mariswamy Y, Gnanaraj WE, Antonisamy JM. FTIR spectroscopic studies on Aerva lanata (L.) Juss. Ex schult. Asian J Pharm Clin Res 2012;5(2):82-6.

50. Birudu RB, Naik MJ, Revana DS, Jilani SK, Janardhan M. Phytochemical screening of ethanolic extract of Passiflora foetida (Linn) and medicinal importance. Indian J Res Pharm Biotechnol 2015;3(4):324-7.

51. Dhawan K, Dhawan S, Sharma A. Passiflora: A review update. J Ethnopharmacol 2004;94(1):1-23

52. Banu BN, Julie J, Abirami J, Kumareasan R, Muthukumaran T, Rajasree S, et al. Anticancer activity of Datura metel on MCF-7 cell line. Asian J Pharm Clin Res 2014;7 Suppl 1:181-3.

53. Rajiv P, Deepa A, Vanathi P, Vidhya D. Screening for phytochemicals and FTIR analysis of Myristica dactyloids fruit extracts. Int J Pharm Pharm Sci 2017:9(1):315-8. 